\title{
Performance Evaluation of PT. Bank Mandiri Tbk based on Balanced Scorecard Method
}

\author{
Harwin Wardhana Dirapradja ${ }^{1}$, Arief Daryanto ${ }^{1}$, Lukman M. Baga ${ }^{1}$ \\ ${ }^{1}$ IPB University, School of Business, Jl. Raya Pajajaran Bogor, Indonesia \\ Corresponding Author: Harwin Wardhana Dirapradja
}

\section{ABSTRACT}

Competing companies not only increase in terms of the number of competitors, but also in terms of the intensity of competition. Today many companies use traditional measurement systems, in such systems there are still shortcomings in providing the information needed to measure and manage all the competencies that can trigger a company's competitive advantage. Given the current business competition environment that is so tight, Bank Mandiri certainly needs a precise performance measurement system that can provide a point of view on the business as a whole in order to compete and even excel in competition. Considering this background, the objectives of this study are: (1) Analyze Bank Mandiri's performance with balanced scorecard concept which includes financial perspective, customer perspective, internal business process perspective, and learning and growth perspective (2) Analyze the factors that must be considered in order to improve the performance of Bank Mandiri (3) Formulate strategic components (vision, mission, policy, and strategic steps) taken by Bank Mandiri. This study employed the descriptive with guided group discussion, in-depth interviews and using Balanced Scorecard analysis. The result showed that, the process of alignment vision to mission, mission to goal, goals to key performance indicators is aligned. The design of the performance-boosting strategy with the Balanced Scorecard approach on Bank Mandiri resulted in 7 strategy objectives and 12 key performance indicators classified into four Balanced Scorecard perspectives. In the formulation of Bank Mandiri's strategy map, customer perspective is at the top, the second position is process perspective, the third position
\end{abstract}

there is people perspective, and at the lowest position there is financial perspective.

Keywords: Balanced Scorecard, Bank Mandiri, Formulate Strategic, Performance Evaluation

\section{INTRODUCTION}

Global competition in today's digital age provides consumers with many choices where they are increasingly cost conscious and value conscious in asking for highquality products and services. In order to survive and succeed in such an environment, the company must create value for customers in the form of quality products and services and services, so that the company will also get value. Companies and organizations need to prioritize consistency through the development of a system that can support the performance of its employees.

Competing companies not only increase in terms of the number of competitors, but also in terms of the intensity of competition. Therefore, in order to maintain competitive extitance, the company must be more effective and efficient and profitable in this case is a strategy to seize the market, marketing strategy or strategy in the existing management system. Today many companies use traditional measurement systems, in such systems there are still shortcomings in providing the information needed to measure and manage all the competencies that can trigger a company's competitive advantage. Traditional measurement systems only emphasize 
financial aspects of measurement, so they are unable to reflect the complexity of all existing corporate activities because they do not take into account other aspects. Though it is known that the financial side is only the outcome of the entire process carried out by the company. Therefore, a measurement system is needed that can connect measurements important to strategic initiatives that can help company management or managers to understand not only what will be achieved, but also how goals can be achieved better.

A good strategy performance measurement system is a system that balances and integrates a variety of important factors of the company that include input, process, and output variables. One strategy performance measurement system that is able to overcome limitations in traditional measurement systems is the Balanced Scorecard measurement system designed by Robert S. Kaplan and David F. Norton, which is a measurement system that is able to evaluate performance by connecting financial and non-financial aspects.

Balanced Scorecard is an indicator and measure of various aspects of a business strategy. In addition, the Balanced Scorecard measures not only the final outcome, but also the activities of determining the final result. With a Balanced Scorecard system, companies are expected to be able to see and determine where value can be created, where investments and improvements need to be made and where certain business strategies can be successfully implemented.

The Balanced Scorecard is used to translate strategies into actions based on the company's vision. The implementation of balanced scorecard can support the need for companies to obtain a comprehensive picture of performance measurements in order to achieve success in the future. The Balanced Scorecard helps managers to view a business from four points of view: a financial perspective, a customer perspective, an internal business process perspective, and a learning and growth perspective. Through the Balanced Scorecard, the company's focus is not only focused on the financial perspective, but managers are also required to pay attention to other perspectives in order to achieve the company's long-term goals.

In this research that is used as an object of research is a service organization engaged in finance, namely banking. Banking has an important role as one of the country's economic cognizing motors. Deteriorating banking performance will have a negative impact on economic development. Therefore, the industry is characterized by a variety of very strict rules. Banking conditions in Indonesia are inseparable from the movement of funds flows. Banking performance in Indonesia is affected by the rapid inflow of capital that is part of the financial system.

PT. Bank Mandiri Tbk was established on October 2, 1998, as part of a banking restructuring program implemented by the Indonesian government. In July 1999, four government banks - namely Bank Bumi Daya, Bank Dagang Negara, Export Import Bank indonesia and Development Bank Indonesia - were merged into PT. Bank Mandiri Tbk, where each bank has an integral role in Indonesia's economic development.

As one of the national banks owned by the government, of course Bank Mandiri is subject to laws, regulations, and otherwise that applies in Indonesia. Therefore, continuous improvements are being made in various fields, especially to answer the challenges faced by the company. Currently, Bank Mandiri's performance measurement system is both financial and non-financial, but there is an imbalance in the value of the company completely because financial and non-financial measurements are seen as two important things that are not correlated.

Bank Mandiri relies on financial performance measurements derived from financial statements and not integrated with other non-financial performance measurements, so the data only shows 
efficiency and cannot show the company's overall capabilities. Given the current business competition environment that is so tight, Bank Mandiri certainly needs a precise performance measurement system that can provide a point of view on the business as a whole in order to compete and even excel in competition.

Along with the increasing number and development of various banking companies, PT. Bank Mandiri Tbk must be able to maintain its existence in the business world and to earn profits that continue to rise. In connection with the development of existing performance measurement tools, as well as the number of competitor banks and efforts to respond to the development of financial technology encourage PT. Bank Mandiri Tbk to always try to find the concept of a performance measurement system that can be in line with the times.

So far, the company's performance is only measured in terms of finances and decision making is based only on these financial data, there has been no overall performance assessment. Performance assessments only on the financial aspect can make it difficult for a company to make a strategic decision because it is only shortterm oriented and financial performance is only the end result. the entire process that the company has done in the past. Of course, this is not rational because the company must consider the circumstances of other factors such as making decisions or determining strategies.

Performance measurements that are overemphasized on a financial point of view, often eliminating other viewpoints that are of course no less important, such as customer satisfaction/loyalty measurements and Employee loyalty, so in a performance measurement requires a balance between the measurement of financial and non-financial performance. This balance can help the company in knowing and evaluating its overall performance.

Based on the description, the author is interested in conducting research, among others (1) How is Bank Mandiri performing when measured by a balanced scorecard approach that includes a financial perspective, customer perspective, internal business process perspective, and learning and growth perspective (2) What factors need to get attention in efforts to improve Bank Mandiri's better performance in the future (3) How to formulate strategic components (vision, mission, policy, and strategic steps) taken by Bank Mandiri.

\section{LITERATURE REVIEW Strategy Management}

Strategy management is a set of managerial decisions and long-term decision-making actions within a company. This includes environmental analysis (external and internal environment), strategy formulation, strategy implementation, and evaluation and control (Wheelen and Hunger, 2012:53). This trategic management can be seen as a process that includes a number of interrelated and sequential stages (Kuncoro, 2006:13). The strategic management process is dynamic and is a set of commitments, decisions, and actions needed by a company or organization to achieve strategic competitiveness and generate above-average profits (Kuncoro, 2006:13).

From the stages of the strategic management process, it can be concluded that strategic management is a set of decisions and actions that result in the formulation and implementation of a plan designed to achieve the goals of a company. Strategic management involves long-term decision-making that is future-oriented as well as complicated and requires considerable resources, hence top management participation is essential (Pearce \& Robinson, 2008:21). With a strategic management approach, managers at all levels of the company interact in their planning and implementation. As a result, the consequences of strategic management behavior are similar to participatory decision-making. Therefore, an accurate assessment of the impact of strategy formulation on organizational performance 
requires not only financial evaluation criteria, but also non-financial behaviorbased impact assessment (Pearce \&Robinson, 2008:13).

\section{Implementation of Strategy}

Strategy implementation is a process by which strategies and policies are directed into action through the development of programs, budgets, and procedures. This process requires changes in the culture, structure, and management system of the entire organization or company (Wheelen and Hunger, 2012:69).

\section{Program}

A program is a statement of the activity or steps needed to complete a plan. Programs are created as a strategy orientation action.

\section{Budget}

A budget is a statement of a company's program in financial condition. In the budget used planning and budget control, so that the budget can be known in detail how much it costs from a program.

\section{Procedure}

A procedure, sometimes said to be Standard Operating Procedures (SOPs), is a system that contains steps or techniques that describe in detail how a specific task or job is done correctly.

\section{Performance Measurement}

The success of strategic achievement needs to be measured, because measurement is a key aspect of performance management on the basis that if it is not measured it will not be able to improve it (Dharma, 2012: 93). Therefore, strategic goals on which performance measurement is based need to be determined in size, and determined strategic initiatives to realize those goals. Strategic goals and their sizes are then used to determine the targets that will be used as a basis for performance assessment, to determine the awards to be given to personnel, teams or organizational units. According to Whittaker in Moeheriono
(2012: 72), performance measurement is a management tool used to improve the quality of decision making and accountability, as well as to assess the achievement of goals and objectives (goal sand objectives).

$$
\text { Meanwhile, according to }
$$

Moeheriono (2012: 96), performance measurement has an understanding of an assessment process of the progress of work towards goals and objectives in the management of human resources to produce goods and services, including information on the efficiency and effectiveness of actions in achieving organizational goals. Thus, a performance measurement is needed that can be used as a foundation to assess the progress that has been achieved compared to the goals that have been set, as well as a communication tool and management tool to improve organizational performance.

From several definitions that have been put forward, it can be concluded that performance measurement is a process of assessing the progress of work achieved by a person or group of people in an organization in accordance with their respective authorities and responsibilities in an effort to achieve organizational goals. However, performance measurements are highly dependent on the performance indicators used. Performance indicators are quantitative and qualitative measures that have been agreed and established, which describe the level of achievement of a predetermined goal or goal. Performance indicators should be something that will be calculated and measured and used as a basis for assessing or looking at performance levels, both in the planning stage, implementation and the stage after the activity is completed and functioning

\section{Key Performance Indicator Concepts}

According to Moeheriono (2012), the Main Performance Indicator is a set of indicators that are considered as key performance indicators both financial and non-financial to carry out operations in an 
organization. The balanced scorecard should describe the overall strategy of the business unit. This is done by combining the result measure or Key Performance Indicator (IKU) with performance driving factors through a series of causal relationships. The result measure tends to be the lagging indicator explaining the main objectives of the strategy and is that short-term efforts have delivered the expected results. Then the measure of the performance driving factor is the leading indicator that explains to all company participants what they must do today to create added value in the future (Kaplan and Norton, 2000).

\section{Balanced Scorecard}

The Balanced Scorecard was created by Robert S. Kaplan, a professor at Harvard Business School, and David P. Norton of public accounting firm KPMG. Both men are from the U.S.A. (Mulyadi, 2007:4). Based on the wording of the Balanced Scorecard, Balanced means balanced. Thus, the Balanced Scorecard is a management tool for maintaining a balance between (Luis and Biromo, 2007:19):

\section{1) Financial and non-financial indicators}

Generally, organizations, especially private companies, are profit-oriented. This is not wrong, but however, there needs to be a balance between profit and achievement with factors that are outside.

\section{2) Indicators of past, present, and future performance}

In fact, financial statements are indicators that assess an organization's past performance. Financial statements cannot be used as a single benchmark to determine future strategies. Financial statements only present data on past achievements.

\section{3) Internal and external indicators}

The balance of internal and external factors relates to the cause-and-effect relationship. Here internal factors are the cause (input) and the output has an impact on external factors. Because they are related, these two indicators must be kept in balance.

\section{4) Leading indicators (Cause/Drivers) and Lagging (Effect/Outcome)}

Going back to the internal and external indicators above, the Balanced Scorecard can describe a clear cause-andeffect relationship. The Balanced Scorecard maps the "causes" that drive the creation of good or poor performance, as well as the "consequences" that can result from those causes.

Furthermore, the word scorecard can literally be translated as "value card" (not the value of the card). This free translation is quite correct, because the Balanced Scorecard is also considered a card in which there are various assessments of the performance achievements of each strategy that has been built (Luis and Biromo, 2007: 23).

The Balanced Scorecard is defined as a performance management tool that can help organizations translate vision and strategy into action by utilizing a set of financial and non-financial indicators that are all established in a causal relationship (Luis and Biromo, 2007: 16). Balanced Scorecard is utilized to balance effort and executive attention to financial and nonfinancial performance, as well as short-term performance and long-term performance (Mulyadi, 2007: 5).

The Balanced Scorecard is supposed to translate the mission and strategy of a business unit into a variety of goals and sizes. The Balanced Scorecard states a balance between the external sizes of shareholders and customers, with various internal measures of important business processes, innovation, and learning and growth (Kaplan and Norton, 1996:10). From these measures, the Balanced Scorecard translates the measure into four perspectives, the four perspectives are as follows: 


\section{a. Financial Perspective}

The Balanced Scorecard still uses a financial perspective because financial measures are critical in providing a summary of the consequences of economic actions already taken. Measures of financial performance provide clues as to whether the company's strategy, implementation, and implementation contribute or not to the increase in the company's profit.

Financial objectives are usually related to profitability, as measured for example by operating profit, return on capital employed (ROCE) or most recently, economic value added. Other financial goals may be rapid sales growth or the creation of cash flow (Kaplan and Norton, 1996:25).

\section{b. Customer's competitive perspective}

In this perspective, managers identify customers and market segments where the business units will compete and various measures of business unit performance within the target segment (Kaplan and Norton, 1996:26).

\section{c. Internal Business Process Perspective}

In the perspective of internal business processes, the persons in charge identify various important internal business processes that must be well mastered by the company. The purpose of the Internal Balanced Scorecard business process is to emphasize the critical processes that support the success of the company's strategy, although some of them may be processes that are not currently implemented at all.

The Balanced Scorecard's internal business process perspective consists of the objectives and measures of the entirely new product and service creation process to meet the growing needs of customers. Therefore, the ability to successfully manage long-term product development processes or capability development to reach new customer categories is more important than the ability to manage current operations efficiently, consistently, and responsively (Summary, 2011:77).
Internal business processes are a series of activities that exist in a business internally that are often called value chains (value chain). In companies that produce goods and services, in general the value chain consists of the development of new products, production, sales and marketing, distribution (product delivery), after sales service, and safety and environmental health (Luisand Biromo, 2007: 31).

The value chain shows the organization as an ongoing process in value creation activities. Value is the amount a buyer is willing to pay for something created by the company. The value is measured from the overall revenue, which is a reflection of the company's set price and the number of products successfully sold (Kuncoro, 2006:46).

In the process of developing new products, organizations strive to create new products that have selling value (Luis and Biromo, 2007: 31). After the product is completed, the organization will enter the next stage, namely the operational process of product income. In this stage, the product will undergo a production process until it becomes a finished product or ready to use. In this perspective a strategy is devised that allows the production process to run smoothly, efficiently, effectively, and optimally. Once completed, the product is sold to customers. The categories of customers here include potential new customers who are expected to buy the product, as well as customers who have used the product who are expected to buy the product back in the future (Luis and Biromo, 2007: 32).

Then the organization can focus on the delivery process which is the process by which the ordered product is completed and distributed to the customer. Furthermore, after the product reaches the customer's hands and they use, there are also facilities that can help customers if the resulting product turns out to be problematic or damaged. Services provided in the period in which the product is used by the customer is called after sales service. Finally, it is 
recommended that the organization is not only oriented towards sales and profit, but also shows responsibility for the surrounding environment. Therefore, the next stage is the stage that includes the policy and environmental process (Luis and Biromo, 2007: 33).

\section{d. Perspective of Learning and Growth}

The fourth perspective of the Balanced Scorecard, learning and growth, identifies the infrastructure that companies must build in creating long-term growth and performance improvement (Kaplan and Norton, 1996:28). The three main sources of corporate learning and growth come from people, systems, and corporate procedures. The financial goals, customers, and internal business processes on the Balanced Scorecard typically show a gap between human resource capabilities, systems and current procedures and what is needed to deliver breakthrough performance. To close this gap, companies must make investments by retraining workers, improving technology and information systems, and aligning the company's various procedures and daily activities. These various objectives are articulated in the perspective of learning and growth balanced scorecard (Kaplan and Norton, 1996:29).

This learning and growth perspective focuses on resources, particularly the human resources within the organization. This perspective deals with the development of human resources, in order for each to become a competent employee that will eventually result in excellent performance for the organization. Therefore, strategic objectives must be to relax strategies in employee training and development (Luis and Biromo, 2007: 37).

\section{METHODS}

This research was conducted at Bank Mandiri which is located at Jl. Jend. Gatot Subroto Kav.36-38 Special Capital Region of Jakarta. The study was conducted over two months starting from August 2021 to September 2021. The data collected is primary data and secondary data. Primary data collection is obtained by way of interviews and focused group discussions with Bank Mandiri leaders and employees, while secondary data is obtained from reports and Other information related to this research. The sampling method in this study is nonprobability sampling with purposive sampling technique. Purposive sampling method is a technique of determining samples with certain considerations. The sample selected to assess the Balanced Scorecard perspective are those who understand and understand the condition of Bank Mandiri. The employees at Bank Mandiri who are made respondents according to their level are distinguished from three, namely Vice President, Assistant Vice President, and Senior Manager.

Primary and secondary data that has been obtained will be processed using Microsoft Excel, until it becomes information that can be applied conceptually with strategy management. Data analysis and processing tools use paired comparison and balanced score card approach methods. Paired comparison is a grain assessment technique that aims to measure a group's attitude towards some items that may be an option or this method can also be used to determine the weight of relevance based on the opinions of a group of people (Djaali and Mulyono, 2008). The stage of analysis that will be carried out on the measurement

Performance with the Balanced Scorecard method with reference to Kaplan and Norton's theory:

\section{A. Alignment}

This method is used to identify alignment and conformity between the vision, mission, objectives and objectives of the strategy and the IKU that already exists in the organization. The validity of the parties concerned is done to get an overview of the alignment and objective view of the circumstances. 


\section{B. Perspective Weight Calculation}

Weight value obtained using the paired comparison method (paired comparison) from the results of filling kuisioner by experts who act as respondents. Respondents gave scores to compare elements on the questionnaire using a scale according to Saaty as stated in Table 3. Consistency in answering each question is necessary. The assessment of the paired comparison continues by using Microsoft Excel so that it gets value for each perspective and key indicator.

\section{Designing a Strategy Map}

The strategy map designed is a consideration of the causal relationship of the strategy objectives in the perspective of the Balanced Scorecard. The basis in compiling a strategy map is the weight value done by the paired comparison method.

\section{Performance Measurement}

The performance measurement framework in Table 4 uses a method of comparing actual achievements against targets that have been set multiplied by the weight of the IKU. Color expression values use conditional formatting in accordance with the information specified in performance management at Bank Mandiri. The standard is very good with the expression of green, both with light green, enough with yellow, less with orange and bad with red.

\section{RESULTS \\ Profile and Characteristics of Bank Mandiri}

Bank Mandiri was established on October 2, 1998, as confirmed by deed No. 10 dated October 2, 1998, which was made before Notary Sutjipto, S.H. Legally formal, the establishment of Bank Mandiri has received approval from the Minister of Justice of the Republic of Indonesia No. C26561. HT.01.01 TH 98 dated October 2, 1998, and was announced in State News of the Republic of Indonesia No. 97 dated
December 4, 1998, Supplementary State News of the Republic of Indonesia No. 6859. Bank Mandiri was born from the merger of four banks in Indonesia, namely PT Bank Bumi Daya (Persero) ("BBD"), PT Bank Dagang Negara (Persero) ("BDN"), PT Bank Ekspor Impor Indonesia (Persero) ("Bank Exim") and PT Bank Pembangunan Indonesia (Persero) ("Bapindo").

In 2003, the company's name changed from PT Bank Mandiri (Persero) to PT Bank Mandiri (Persero) Tbk. based on changes in the articles of association confirmed through notary deed Sutjipto, S.H., No. 2 dated June 1, 2003. The change has been approved by the Minister of Law and Human Rights of the Republic of Indonesia based on Decree No.C-12783. HT.01.04.TH.2003 dated June 6, 2003, and was announced at State News of the Republic of Indonesia No. 63 dated August 8, 2003, Supplementary State News of the Republic of Indonesia No. 6590. The name change was followed by a corporate action in the form of the sale of initial public offering (IPO) of Bank Mandiri on July 14, 2003. Recorded as many as $4,000,000,000$ pieces of Series B Common Stock sold at a face value of Rp500 (full value) per share, which was sold at a price of Rp675 (full value) per share. This corporate action is a divestment of $20.00 \%$ of Bank Mandiri's government-owned shares. On the same date, Bank Mandiri then listed as many as 19.8 million shares of Series B Common Stock on the Jakarta Stock Exchange and Surabaya Stock Exchange. With the corporate action, namely the sale and listing of the initial shares, Bank Mandiri's status automatically changed from a closed company to an open company.

\section{Alignment}

The initial stages will be done in designing performance measurements with the Balanced Scorecard approach, namely alignment or alignment. Expected performance will be better, must be followed by a structured and clear procedure that is able to describe the vision, mission, 
and strategy of the organization (Brillianty and Bendatu, 2013). Alignment vision to mission, mission to goal, goal to goal, and goal to key performance indicators will be described in the following sub-headings

Vision is a statement that describes the expectations of the organization that wants to be realized containing directions and actions that will be carried out by the organization in the future expressed clearly and concisely, while the mission is an effort in achieving the vision that has been set with short-term and long-term activities (Moeheriono, 2012). Designing a vision and mission well is essential in formulating, implementing, and evaluating organizational strategies (David, 2004). Therefore, alignment is needed to know the alignment between the vision and mission of the organization illustrated in the figure 1.

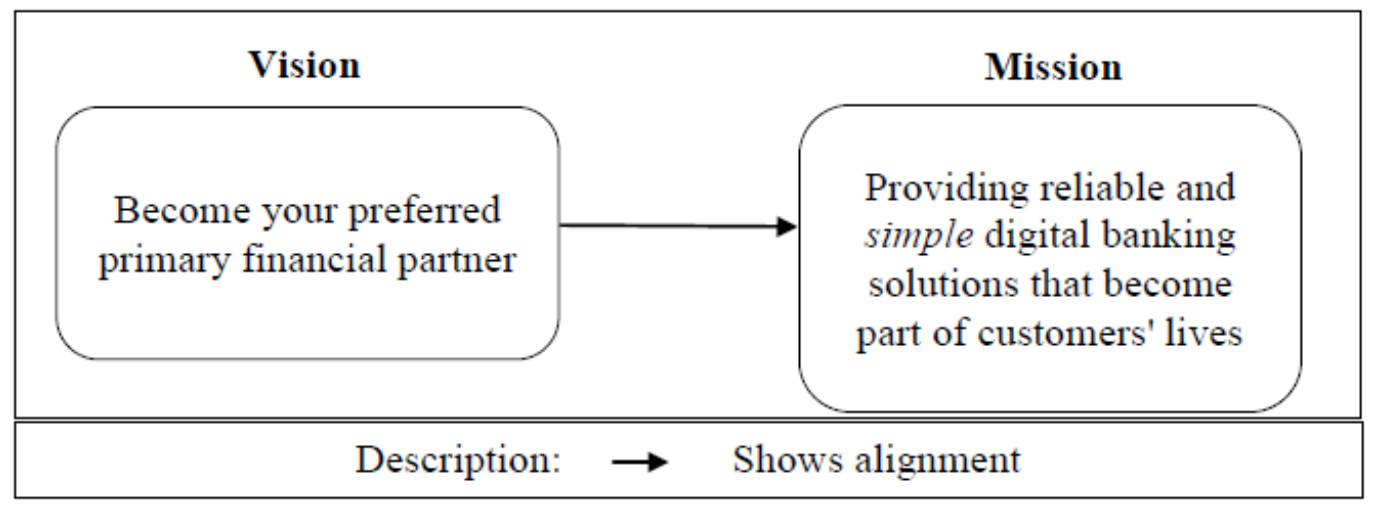

Source: Internal Bank Mandiri (2021)

Figure 1 Alignment between the vision and mission of the organization

The image above shows that the vision and mission are aligned(inline). There are important points listed in the vision that have been spelled out into the mission of Bank Mandiri. Achieving this vision requires various preparations and readiness from all Employees of Bank Mandiri.
After do Alignment vision to mission, Stages Next be do Alignment mission to purpose. Purpose be results that must Reached by organization with Sharpen focus towards Targets that more Specific and real (Moeheriono, 2012). Harmony mission and purpose necessary Done analysis with make Alignment mission to purpose that get views at Figure 2.

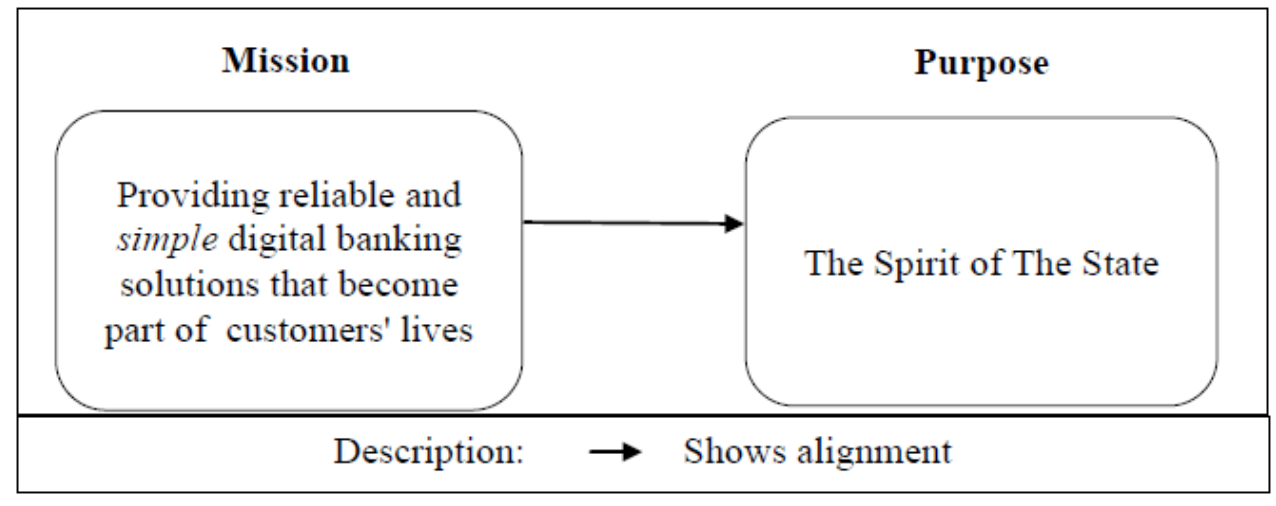

Source: Internal Bank Mandiri (2021)

Figure 2 Alignment of Bank Mandiri's vision to the mission of Bank Mandiri

Figure 2 shows that the mission is in line with the objectives set in realizing the mission. The purpose of Bank Mandiri is spirit of prospering the country that can be felt the benefits by Bank Mandiri and the state of Indonesia. The third stage of the alignment process is to analyze the alignment between Bank Mandiri's objectives and the goals set by Bank Mandiri. Goals are tools to mobilize the 
Harwin Wardhana Dirapradja et.al. Performance evaluation of PT. Bank Mandiri Tbk based on balanced scorecard method.

organization's resources and energy to realize the future. Alignment of goals and objectives needs to be analyzed by making alignment goals to goals that can be seen in Figure 3.

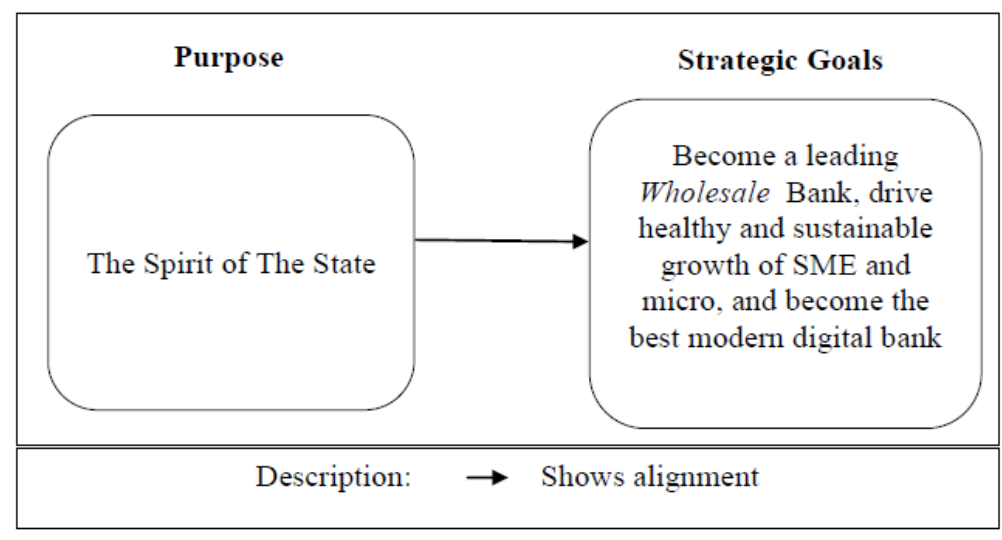

Source: Internal Bank Mandiri (2021)

Figure 3 Alignment of Bank Mandiri's objectives to the strategic mission of Bank Mandiri

Figure 3 shows that the strategic objectives of being a leading wholesale bank, fostering healthy and sustainable growth of SME and micro, and being the best modern digital bank are supporting the achievement of Bank Mandiri's objectives.

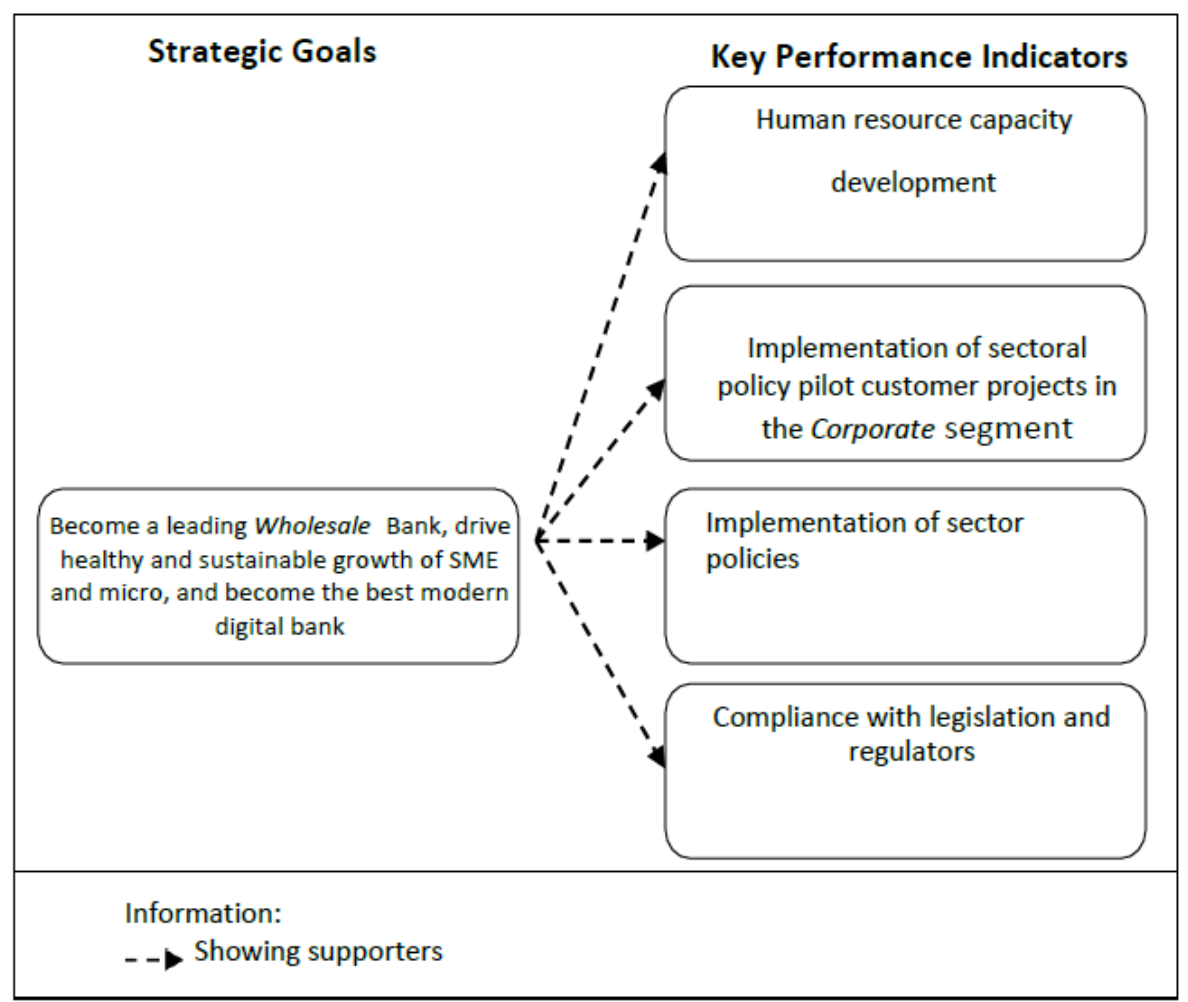

Source: Internal Bank Mandiri (2021)

Figure 4 Alignment of Bank Mandiri's objectives to the strategic mission of Bank Mandiri

The fourth stage of the alignment process is to analyze the alignment between Bank Mandiri's objectives and Bank Mandiri's key performance indicators in the Bank Mandiri Performance Agreement 2020. The main performance indicators explain what must be done so that the achievement of the performance that has been set can be implemented continuously. Alignment of targets with key performance indicators can be seen in Figure 4.

Figure 4 shows the main performance indicators to be a contributing factor to the achievement of Bank Mandiri's 
Harwin Wardhana Dirapradja et.al. Performance evaluation of PT. Bank Mandiri Tbk based on balanced scorecard method.

strategic objectives. Designing performance measurements using the BSC method requires key performance indicators that describe all four perspectives, so the design of key performance indicators is needed at a later stage.

\section{Bank Mandiri Performance Measurement Strategy Design with Balanced Scorecard}

According to Kaplan and Norton (2000) the successful implementation of a good Balanced Scorecard should have 2 measures, namely the lagging indicator and the performance trigger size (Leading Indicator) that is in accordance with the targets of the strategy to be achieved. The size of the results is a reflection of the achievement of the strategy objectives, while the size of the performance trigger is a driving factor in the achievement of the size of the results. The process of formulating a strategy is a series of activities to find the right strategy for the organization (Febrina, 2012).

Table 1 Measure of Performance Achievement of Bank Mandiri’s BSC strategy

\begin{tabular}{|c|c|c|}
\hline \multirow[t]{2}{*}{ Strategy objectives } & \multicolumn{2}{|l|}{ Strategy size } \\
\hline & Trigger size & Result size \\
\hline \multicolumn{3}{|l|}{ Process } \\
\hline \multirow[t]{5}{*}{ Modern Digital Retail Bank } & Active user Livin' by Mandiri & $\begin{array}{l}\text { Active user Livin'by Mandiri increased in } 2021 \text { and better than } \\
2020\end{array}$ \\
\hline & Ending Balance total credit & $\begin{array}{l}\text { Ending Balance total credit minimum in accordance with RKAP } \\
\text { Revision } 2021\end{array}$ \\
\hline & Net Promoter Score (NPS) & Net Promoter Score (NPS) is better than in 2020 \\
\hline & Cybersecurity Breach Incident & There was no cybersecurity breach incident. \\
\hline & IT Maturity Level & IT Maturity Level at least reaches level 3 \\
\hline Quality credit growth & Cost of Credit & $\begin{array}{l}\text { Cost of Credit is reached maximum in accordance with RKAP } \\
\text { revision } 2021\end{array}$ \\
\hline \multicolumn{3}{|l|}{ Browse } \\
\hline \multirow[t]{2}{*}{$\begin{array}{l}\text { High performing corporate } \\
\text { culture }\end{array}$} & $\begin{array}{l}\text { Employee Development Index which } \\
\text { includes the implementation of } \\
\text { training and Individual Development } \\
\text { Plan }\end{array}$ & $\begin{array}{l}\text { \% of employees who carry out training at least } 3 x \text { and who } \\
\text { complete IDP by } 80 \%\end{array}$ \\
\hline & $\begin{array}{l}\text { Preparation of talent development } \\
\text { program in accordance with the } \\
\text { direction of the Ministry of SOEs }\end{array}$ & $\begin{array}{l}\text { Endorsement and approval of the establishment of a cluster/ sub- } \\
\text { cluster of SOEs Institute including the succession program of the } \\
\text { Board of Directors and the development of young top talent }\end{array}$ \\
\hline \multicolumn{3}{|r|}{ ( } \\
\hline $\begin{array}{l}\text { Improving bank positioning } \\
\text { in the industry through } \\
\text { innovation }\end{array}$ & $\begin{array}{l}\text { Implementation of strategic business } \\
\text { model improvement initiatives }\end{array}$ & $\begin{array}{l}\text { Implementation of strategic initiatives Business } \\
\text { Improvement is reached according to milestones }\end{array}$ \\
\hline $\begin{array}{l}\text { Strengthening } \\
\text { financial/financial pasitas to } \\
\text { the people of Indonesia }\end{array}$ & $\begin{array}{l}\text { KUR distribution, credit distribution } \\
\text { from PEN funds, effective yield of } \\
\text { PEN credit }\end{array}$ & $\begin{array}{l}\text { Kur distribution is at least in accordance with the target of the } \\
\text { government, the distribution of credit from PEN Funds is at least } \\
3 \text { times that of PEN funds, effective PEN credit yield is higher } \\
\text { than required PEN credit yield }\end{array}$ \\
\hline $\begin{array}{lr}\text { Improved } & \text { corporate } \\
\text { governance and strategic } \\
\text { partner cooperation }\end{array}$ & $\begin{array}{l}\text { Score } \quad \text { Corporate } \quad \text { Governance } \\
\text { Perception Index (SCGPI) }\end{array}$ & $\begin{array}{l}\text { Score Corporate Governance Perception Index (SCGPI) better } \\
\text { than in } 2020\end{array}$ \\
\hline \multicolumn{3}{|l|}{ Financial } \\
\hline $\begin{array}{l}\text { Expansion of operations and } \\
\text { strengthening of capital }\end{array}$ & $\begin{array}{l}\text { Pre-provision Operating Profit, Net } \\
\text { Profit After Tax, Capital Adequacy } \\
\text { Ratio }\end{array}$ & $\begin{array}{l}\text { PPOP, NPAT, and CAR achieved at least in accordance with } \\
\text { RKAP Revision } 2021\end{array}$ \\
\hline
\end{tabular}

Source: Internal Bank Mandiri (2021)

Determination of goals, trigger size and size of results obtained through the results of discussions. There are 3 measures of results, namely the Score Corporate Governance Perception Index (SCGPI) on corporate governance and strategic partner cooperation, Business Model Improvement, and the percentage of PPOP, NPAT, and CAR values which are the main performance indicators of Bank Mandiri in
2021 which is considered still in accordance with the condition of Bank Mandiri to design and measure the performance of Bank Mandiri units using Balanced Scorecard.

Bank Mandiri's 4 strategic objectives in the process perspective, namely active user Livin'by Mandiri, Ending Balance total credit, Net Promoter Score (NPS), Cybersecurity Breach 
Harwin Wardhana Dirapradja et.al. Performance evaluation of PT. Bank Mandiri Tbk based on balanced scorecard method.

Incident, IT Maturity Level, Cost of Credit. strategy objectives are listed in the process Trigger indicators and results indicators used to measure the achievement of the perspective scorecard.

Table 2 Process Perspective Scorecards

\begin{tabular}{|c|c|c|c|c|c|c|}
\hline Trigger Indicator & Key Performance Indicators & $\begin{array}{l}\text { IKU } \\
\text { Weight }\end{array}$ & $\begin{array}{l}\text { Standard } \\
\text { Determinat }\end{array}$ & & $\begin{array}{l}\text { Baseline } \\
(2021)(\%)\end{array}$ & $\begin{array}{l}\text { Target } \\
(2021)(\%)\end{array}$ \\
\hline \multirow{3}{*}{$\begin{array}{l}\text { Net Promoter Score } \\
\text { (NPS) }\end{array}$} & \multirow{3}{*}{$\begin{array}{l}\text { Net Promoter Score (NPS) is better } \\
\text { than in } 2020\end{array}$} & & Excellent & $\geq 100$ & & \\
\hline & & & Good & $76-99$ & \multirow[t]{2}{*}{142.55} & \multirow[t]{2}{*}{100} \\
\hline & & 0.014 & Enough & $61-75$ & & \\
\hline & & & Less & $51-60$ & & \\
\hline & & & Bad & $\leq 50$ & & \\
\hline \multirow{5}{*}{$\begin{array}{l}\text { Cybersecurity } \\
\text { Breach Incident } \\
\end{array}$} & \multirow{4}{*}{$\begin{array}{l}\text { There was no cybersecurity breach } \\
\text { incident. }\end{array}$} & & Excellent & \multicolumn{3}{|l|}{$\geq 100$} \\
\hline & & & Good & $76-99$ & \multirow[t]{2}{*}{100} & \multirow[t]{2}{*}{100} \\
\hline & & 0.026 & Enough & $61-75$ & & \\
\hline & & & Less & $51-60$ & & \\
\hline & & & Bad & $\leq 50$ & & \\
\hline \multirow[t]{5}{*}{ Cost of Credit } & \multirow{4}{*}{$\begin{array}{l}\text { Cost of Credit is reached maximum in } \\
\text { accordance with RKAP revision } 2021\end{array}$} & & Very Good & \multicolumn{3}{|l|}{$\geq 100$} \\
\hline & & & Good & $76-99$ & & \\
\hline & & 0.038 & Enough & $61-75$ & 100 & 100 \\
\hline & & & Less & $51-60$ & & \\
\hline & & & Bad & $\leq 50$ & & \\
\hline \multirow{5}{*}{$\begin{array}{l}\text { Active user Livin' } \\
\text { by Mandiri }\end{array}$} & \multirow{4}{*}{$\begin{array}{l}\text { Livin' by Mandiri active user } \\
\text { increases in } 2021 \text { and better than } \\
2020\end{array}$} & & Very Good & \multicolumn{3}{|l|}{$\geq 100$} \\
\hline & & & Good & $76-99$ & \multirow[t]{2}{*}{100} & \multirow[t]{2}{*}{100} \\
\hline & & 0.071 & Enough & $61-75$ & & \\
\hline & & & Less & $51-60$ & & \\
\hline & & & Bad & $\leq 50$ & & \\
\hline \multirow{5}{*}{$\begin{array}{l}\text { Ending Balance } \\
\text { total credit }\end{array}$} & \multirow{4}{*}{$\begin{array}{l}\text { Ending Balance total credit minimum } \\
\text { in accordance with RKAP Revision } \\
2021\end{array}$} & & Very Good & \multicolumn{3}{|l|}{$\geq 100$} \\
\hline & & & Good & $76-99$ & \multirow[t]{2}{*}{100} & \multirow[t]{2}{*}{100} \\
\hline & & 0.071 & Enough & $61-75$ & & \\
\hline & & & Less & $51-60$ & & \\
\hline & & & Bad & $\leq 50$ & & \\
\hline \multirow[t]{5}{*}{ IT Maturity Level } & IT Maturity Level at least reaches & & Very Good & $\geq 100$ & & \\
\hline & level 3 & & Good & $76-99$ & \multirow[t]{2}{*}{100} & \multirow[t]{2}{*}{100} \\
\hline & & 0.019 & Enough & $61-75$ & & \\
\hline & & & Less & $51-60$ & & \\
\hline & & & Bad & $\leq 50$ & & \\
\hline
\end{tabular}

Table 2 shows the results of weighting IKU process perspective. The main performance indicator (IKU) with the highest weight value of 0.071 is Active user Livin' by Mandiri and Ending Balance total credit. This shows that the IKU is considered important and influential on the achievement of performance in the process perspective. The target of achieving 2021 or baseline 2021 overall in the process perspective has been very good.

Table 3 People Perspective Scorecards

\begin{tabular}{|c|c|c|c|c|c|c|}
\hline Trigger Indicator & Key Performance Indicators & $\begin{array}{l}\text { IKU } \\
\text { Weight }\end{array}$ & $\begin{array}{l}\text { Standard } \\
\text { Determinat }\end{array}$ & & $\begin{array}{l}\text { Baseline } \\
(2021) \\
(\%)\end{array}$ & $\begin{array}{l}\text { Target } \\
(2021) \\
(\%)\end{array}$ \\
\hline \multirow{3}{*}{$\begin{array}{l}\text { Employee } \\
\text { Index which includes the } \\
\text { implementation of training } \\
\text { and Individual Development } \\
\text { Plan }\end{array}$} & \multirow{3}{*}{$\begin{array}{l}\% \text { of employees who carry out } \\
\text { training at least } 3 x \text { and who complete } \\
\text { IDP by } 80 \%\end{array}$} & & Very Good & \multicolumn{3}{|l|}{$\geq 100$} \\
\hline & & & Good & $76-99$ & & \\
\hline & & 0.063 & Enough & $61-75$ & 100 & 100 \\
\hline & & & Less & $51-60$ & & \\
\hline & & & Bad & $\leq 50$ & & \\
\hline \multirow{5}{*}{$\begin{array}{l}\text { Preparation of talent } \\
\text { development program in } \\
\text { accordance with the direction } \\
\text { of the Ministry of SOEs }\end{array}$} & \multirow{5}{*}{$\begin{array}{l}\text { Endorsement and approval of the } \\
\text { establishment of a cluster / sub-cluster } \\
\text { of SOEs Institute including the } \\
\text { succession program of the Board of } \\
\text { Directors and the development of } \\
\text { young top talent }\end{array}$} & & Excellent & $\geq 100$ & & \multirow{5}{*}{100} \\
\hline & & & Good & $76-99$ & & \\
\hline & & 0.037 & Enough & $61-75$ & 75 & \\
\hline & & & Less & $51-60$ & & \\
\hline & & & Bad & $\leq 50$ & & \\
\hline
\end{tabular}

p-value: Standard Determination

Source: Internal Bank Mandiri (2021)

The target strategy in people corporate culture. High performing perspective is kultur or high performing corporate culture measures 2 key 
performance indicators and 2 trigger indicators listed in the people perspective scorecard in Table 3. The Employee Development Index which includes the implementation of training and the Individual Development Plan obtained the highest IKU weight value of 0.063 and with a baseline category of 2021 was very good. The preparation of talent development programs in accordance with the direction of the Ministry of SOEs at baseline 2021 is still in the sufficient category. Therefore, the IKU should be more considered for improvement.

Customer perspective at Bank Mandiri sets 3 strategic objectives, namely enhancing bank positioning in the industry through innovation, strengthening financial / financial capacity to the people of Indonesia, and the improvement of corporate governance and strategic partner cooperation. The target of the strategy is measured by 3 main performance indicators and trigger indicators listed in the customer perspective scorecard in Table 4.

The value of IKU weighting to the people of Indonesia has the highest value in customer perspective of 0.349 with a baseline of 2021 in the category is very good and has reached the target of 2021 set. In the percentage indicator of the Score Corporate Governance Perception Index (SCGPI), the corporate governance assessment category is divided into 7 categories namely AA, A, BB, B, CC, C, D. For Bank Mandiri itself, AA is categorized on excellent standards, A on Good standards, BB on sufficient standards, B on less CC standards on bad standards, and the rest not used because That assessment is very low.

Table 4 Customer Perspective Scorecard

\begin{tabular}{|c|c|c|c|c|c|c|}
\hline Trigger Indicator & Key Performance Indicators & IKU & Standard & ination & & Target \\
\hline Corporate & Score Corporate Governance Perception & & Excellent & $>100$ & & \\
\hline Governance Perception & Index (SCGPI) better than in 2020 & & Good & $76-99$ & & \\
\hline Index (SCGPI) & & 0.057 & Enough & $61-75$ & 73.31 & 100 \\
\hline & & & Less & $51-60$ & & \\
\hline & & & Bad & $\leq 50$ & & \\
\hline Implementation of & Implementation of strategic initiatives & & Excellent & $\geq 100$ & & \\
\hline $\begin{array}{l}\text { strategic business model } \\
\text { improvement initiatives }\end{array}$ & $\begin{array}{l}\text { business model improvement achieved in } \\
\text { accordance with milestones }\end{array}$ & & Good & $76-99$ & & \\
\hline & & 0.117 & Enough & $61-75$ & 74.79 & 70 \\
\hline & & & Less & $51-60$ & & \\
\hline & & & Bad & $\leq 50$ & & \\
\hline KUR distribution, credit & Kur distribution is at least in accordance & & Excellent & $\geq 100$ & & \\
\hline $\begin{array}{l}\text { distribution from PEN } \\
\text { funds, effective yield of } \\
\text { PEN credit }\end{array}$ & $\begin{array}{l}\text { with the target of the government, the } \\
\text { distribution of credit from PEN Funds at } \\
\text { least } 3 \text { times from PEN funds, effective } \\
\text { PEN credit yield is higher than required } \\
\text { pen credit yield }\end{array}$ & 0.349 & Good & $76-99$ & 100 & 100 \\
\hline & & & Enough & $61-75$ & & \\
\hline & & & Less & $51-60$ & & \\
\hline
\end{tabular}

p-value: Standard Determination

Source: Internal Bank Mandiri (2021)

The Category of Score Corporate Governance Perception Index (SCGPI) and the value of the results of the implementation of strategic initiatives Business Model Improvement are included in the category sufficient at the baseline of 2021. However, the target setting is still low by taking the standard range of categories sufficiently on the yield value indicator according to Bank Mandiri's milestone.
Kur distribution assessment is the distribution of KUR at least in accordance with the target of the government, the assessment of credit distribution from PEN Funds is the distribution of PEN funds at least 3 times from PEN funds, the effective assessment of PEN credit yield is effective pen credit yield is higher than required yield credit PEN.

Expansion of operations and strengthening of capital are strategic 
Harwin Wardhana Dirapradja et.al. Performance evaluation of PT. Bank Mandiri Tbk based on balanced scorecard method.

objectives set by Bank Mandiri in financial perspective. The target of the strategy measures 1 main performance indicator and
1 trigger indicator. Financial perspective scorecard at Table 5.

Table 5 Financial Scorecard Perspective

\begin{tabular}{|c|c|c|c|c|c|c|}
\hline Trigger indicator & Key performance indicators & $\begin{array}{l}\text { IKU Weight } \\
\text { (a) }\end{array}$ & Standards & & $\begin{array}{l}\text { Baseline } \\
\text { (2015) } \\
(\%)\end{array}$ & $\begin{array}{l}\text { Target } \\
\text { (2015) } \\
(\%)\end{array}$ \\
\hline \multirow{5}{*}{$\begin{array}{l}\text { Pre-povision Operating Profit, } \\
\text { Net Profit After Tax, Capital } \\
\text { Adequacy Ratio }\end{array}$} & \multirow{3}{*}{$\begin{array}{l}\text { PPOP, NPAT, and CAR } \\
\text { achieved at least in accordance } \\
\text { with RKAP Revision } 2021\end{array}$} & & Very Good & $\geq 100$ & \multirow{5}{*}{96.58} & \multirow{5}{*}{100} \\
\hline & & & Good & $76-99$ & & \\
\hline & & 0.055 & Enough & $61-75$ & & \\
\hline & & & Less & $51-60$ & & \\
\hline & & & Bad & $\leq 50$ & & \\
\hline
\end{tabular}

p-value: Standard Determination

Source: Internal Bank Mandiri (2021)

Achievements in 2021 Pre-provision Operating Profit, Net Profit After Tax, Capital Adequacy Ratio were achieved at least in accordance with RKAP Revision 2021 to Bank Mandiri's program and performance included in the good category and has reached the targets set. This shows that Bank Mandiri in financial or financial aspects has shown good performance, both in terms of profit or profit obtained in 2021 and The adequacy of capital owned to carry out operations and duties as one of the Agents of Development who actively supports the success of Bank Mandiri's goal, namely Spirit To Prosper the Country.

\section{Managerial Implications}

\begin{tabular}{|c|c|c|c|c|}
\hline No. & Perspective & $\begin{array}{l}\text { Strategy } \\
\text { objectives }\end{array}$ & Improvement & Sustainable development \\
\hline \multirow[t]{3}{*}{1} & Process & $\begin{array}{l}\text { Modern Digital } \\
\text { Retail Bank }\end{array}$ & $\begin{array}{l}\text { Improved service at branch offices and e- } \\
\text { Banking } \\
\text { Improve security against Insider and external } \\
\text { cyber threats and the ability to conduct digital } \\
\text { forensics that supports the security incident } \\
\text { investigation process and ensures post-incident } \\
\text { recovery }\end{array}$ & $\begin{array}{l}\text { Add a number of new features in the Livin' by } \\
\text { Mandiri app to facilitate customer transactions } \\
\text { Launching Kopra by Mandiri as a pioneer of } \\
\text { wholesale super platform in the sustainable } \\
\text { banking industry } \\
\text { Optimizing business potential in leading } \\
\text { regions and sectors as well as sectors that } \\
\text { recover faster } \\
\text { Improve infrastructure and IT operations such } \\
\text { as Data Center facilities, Disaster Recovery } \\
\text { Center, and Core banking systems }\end{array}$ \\
\hline & & $\begin{array}{l}\text { Quality credit } \\
\text { growth }\end{array}$ & & $\begin{array}{l}\text { 5. Implementation of restructuring for debtors } \\
\text { affected by COVID-19 }\end{array}$ \\
\hline & & $\begin{array}{l}\text { Quality credit } \\
\text { growth }\end{array}$ & & $\begin{array}{l}\text { 6. Close monitoring in the provision of new } \\
\text { credit }\end{array}$ \\
\hline 2 & Browse & $\begin{array}{l}\text { High } \\
\text { performing } \\
\text { corporate } \\
\text { culture }\end{array}$ & & $\begin{array}{l}\text { Planning and ensuring the education and } \\
\text { training held will support and make a real } \\
\text { impact on the Bank's business } \\
\text { In collaboration with the Ministry of SOEs to } \\
\text { design Mandiri University as a learning center } \\
\text { for the succession program of directors and the } \\
\text { development of young top talent throughout } \\
\text { SOEs }\end{array}$ \\
\hline
\end{tabular}

Based on the results of performance measurements using the balanced scorecard method, the performance score from Bank Mandiri in2021 was $90.43 \%$ or performed well. Through balanced Scorecard, banking organizations will be able to explain their mission to the public or stakeholders and can identify indicators of stakeholder satisfaction in a more transparent, objective, measurable manner and able to identify the work process and quality of human resources needed in achieving its mission and strategy (Effendi, 2012). There are managerial implications that are groupings of strategy initiatives.

The implementation of performance measurement using the balanced scorecard (BSC) approach provides information about bank mandiri's condition comprehensively. The design and preparation of the balanced 
scorecard framework adjusts in vision, mission, objectives, strategy objectives, targets, strategy initiatives and includes key performance indicators that do not yet exist on Bank Mandiri but these indicators can be a trigger for the performance of Bank Mandiri units. Performance measurement with a balanced scorecard approach can be a direction for Bank Mandiri to be strategyoriented. The balanced scorecard approach can be used as included in the improvement of Bank Mandiri's regulations more comprehensively by including all financial and nonfinancial aspects in Bank Mandiri, more balanced with regard to short-term and long-term goals, and between the desired performance results and the driving factors of achieving results, and can explain the relationship. causation of the achievement of performance indicators contained in the strategy map, as well as the performance results of output and outcomes that are more measurable.

\section{CONCLUSION}

The process of alignment vision to mission, mission to goal, goals to key performance indicators is aligned. However, the process of alignment goals to targets, targets become a supporting factor in achieving the objectives of Bank Mandiri. The design of the performance-boosting strategy with the Balanced Scorecard approach on Bank Mandiri resulted in 7 strategy objectives and 12 key performance indicators classified into four Balanced Scorecard perspectives. Strategy maps describe causal relationships in each perspective. In the formulation of Bank Mandiri's strategy map, customer perspective is at the top, the second position is process perspective, the third position there is people perspective, and at the lowest position there is financial perspective. Performance measurement results with the Balanced Scorecard approach as a whole belong to the good category. This indicates that Bank Mandiri has carried out its duties and functions effectively. that PT. ERP has a very low growth rate of $-13 \%$ per year on average but its market share is still small compared to its five main competitors. Position of PT. ERP on BCG matrix is on kwadran "dogs" which means PT. ERP is at a low growth rate and controls only a low market share.

\section{Acknowledgement: None}

\section{Conflict of Interest: None}

\section{Source of Funding: None}

\section{REFERENCES}

1. Brillianty SF, Bendatu LY. 2013. Perancangan alat ukur penilaian kinerja di PT X dengan menggunakan balanced scorecard. Jurnal Titra. 1(2):149-156.

2. Dave, S, Dave, S, Applying Balanced Scorecard in Indian Banking Sector: An Empirical Study of the State Bank of India, Pacific Business Review International. Volume 5 Issue 6, December 2012

3. David FR. 2004. Manajemen Strategi: Konsep. Sindoro A, penerjemah; Widyantoro A, editor. Jakarta (ID): PT INDEKS. Terjemahan dari : Pretice Hall.

4. Dharma, Surya. "Manajemen Kinerja Falsafah Teori dan Penerapannya", Yogyakarta, Pustaka Pelajar. 2012.

5. Gustika A. "Rancangan dan Evaluasi kinerja pada PT Bank Muamalat Indonesia Tbk cabang Serang dengan Balanced Scorecard”, Bogor, Institut Pertanian Bogor. 2011.

6. Hunger, J. David dan Wheelen, Thomas L. "Manajemen Strategis", Yogyakarta, Penerbit Andi. 2003.

7. John A. Pearce dan Richard B. Robinson. "Manajemen Strategis-Formulasi, Implementasi, dan Pengendalian”, Jakarta, Salemba Empat. 2008.

8. Kaplan, Robert S. dan David P. Norton. "Balanced Scorecard: Menetapkan Strategi Menjadi Aksi”, Erlangga, Jakarta, 2000.

9. Khairi A. "Analisis Pengukuran Kinerja Organisasi Berbasis Balanced corecard pada Dinas Bina Marga dan Sumber Daya Air Kota Bogor”, Bogor, Institut Pertanian Bogor. 2016. 
Harwin Wardhana Dirapradja et.al. Performance evaluation of PT. Bank Mandiri Tbk based on balanced scorecard method.

10. Kotler, Philip dan Kevin Lane Keller. "Marketing Management, 13th Edition", Jakarta, 2013.

11. Kuncoro, Murdrajat. "Ekonomi Pembangunan”, Penerbit Salemba Empat, Jakarta. 2006.

12. Luis, S., dan Biromo, P.A. "Step by Step in Cascading Balanced Scorecard to Funcional Scorecards”, Jakarta, PT Gramedia Pustaka Utama. 2007.

13. Moeheriono. "Pengukuran Kinerja Berbasis Kompetensi”, Jakarta, Raja Grafindo Persada. 2012.

14. Mulyadi. "Balanced Scorecard: Alat Manajemen Kontemporer Untuk Pelipatgandaan Kinerja Keuangan
Perusahaan”, Jakarta, Edisi Kelima, Salemba Empat. 2007.

15. Rangkuti, Freddy. "SWOT Balanced Scorecard”, Jakarta, PT Gramedia Pustaka Utama. 2011.

16. Zizlavsky, Ondrej. "The Balanced Scorecard: Innovative Performance Measurement and Management Control System”, Vol. IX Issue 3, 2014.

How to cite this article: Dirapradja HW, Daryanto A, Baga LM. Performance evaluation of PT. Bank Mandiri Tbk based on balanced scorecard method. International Journal of Research and Review. 2021; 8(11): 175-190. DOI: https://doi.org/10.52403/ijrr.20211124 